\title{
Spatial analysis of fire characteristies along with various gradients of season, administrative units, vegetation, socio-economy, topography and future climate change: A case study of Orissa state in India
}

\author{
Firoz Ahmad $^{1}$, Md Meraj Uddin ${ }^{2}$, Laxmi Goparaju ${ }^{*}$ \\ ${ }^{1}$ Vindhyan Ecology and Natural History Foundation, Mirzapur, Uttar Pradesh, India \\ ${ }^{2}$ University Department of Mathematics, MCA, Ranchi University, Ranchi, Jharkhand, India, \\ *e-mail: goparajulaxmi@yahoo.com
}

Received: 23 April 2018 / Accepted: 25 June 2018

\begin{abstract}
Fire events are an increasing phenomenon these days due to the climate change. It is responsible for forest degradation and habitat destruction. Changes in ecosystem processes are also noticed. The livelihood of tribal population is also threatened. Geospatial technologies along with Remotely Sensed data have enormous capability to evaluate the various diversified datasets and to examine their relationship.

In this analysis, we have utilized the long term fire events at district level for the Orissa state of India and forest fire hotspots were identified. The fire pattern was analyzed with respect to the existing vegetation types, tribal population and topography to understand its association/relationship. Furthermore, it was evaluated with future climate change data for better comprehension of future forest fire scenario.

The study reveals that Kandhamal, Raygada and Kalahandi district have highest fire frequency representing around 38\% of the total Orissa fire events. The vegetation type "Tropical mixed deciduous and dry deciduous forests" and "Tropical lowland forests, broadleaved, evergreen, $<1000 \mathrm{~m}$ " occupy the geographical area roughly $43 \%$ whereas they retain fire percent equivalent to $70 \%$. Approximately $70 \%$ of forest fire occurred in the area where tribal population was high to very high. The $60 \%$ of forest fire occurred where elevation was greater than 500 meters whereas $48 \%$ of fire occurred on moderate slopes.

Our observation of future climate change scenario for the year 2030 reflects the increase in summer temperature and irregular rainfall pattern. Therefore, forest fire intensity will be more in future in the state of Orissa whereas it's intensity will be more severe in few of the district such as Kandhamal, Raygada, Kalahandi and Koraput which have significantly high forest fire events in present scenario.

The outcomes of the present study would certainly guide the policymakers to prepare more effective plan to protect the forest which is main source of livelihood to the tribal population keeping in mind of future climate change impact for prioritization of various districts of state of Orissa suffering from forest fires.
\end{abstract}

Keywords: forest fire events, forest fire hotspot, socio-economy, topography, climate change scenario (RCP-6), Orissa.

\section{Introduction}

Climate and bio-physical environment (e.g., weather, soils, topography, and vegetation) of a region control the natural fire regimes (Gedalof, 2011). Fire regimes (frequency, intensity, size, pattern, season, and severity) are important contributors in many ecosystems (Bond \& Keeley, 2005; Gill, 1975). Climate change of any region adversely impacts on cultural, ecological values and socioeconomic condition of inhabitant tribal community (Voggesser et al., 
2013) by increasing the frequency and intensity of fires, higher temperatures, drought leads to extreme changes to their ecosystem processes, forest habitat degradation. Rising temperatures, hotter and drier summers, and wildfires are expected to increase in the frequency, intensity, and severity (Moritz et al., 2012). Droughts, as well as tree mortality and vegetation stress, will result in longer fire seasons (Flannigan et al., 2005) by increasing the fuel load (Finney, 2001), plant disease (Sturrock et al., 2011), insect outbreaks (Hicke et al., 2012) and the spread of invasive species (NWF, 2011).

The enhancement of sensors in satellite remote sensing has strengthened the opportunity for mapping various natural resources, monitor/assess natural calamities and can be successfully used to monitor fire patterns (Ager et al., 2017; Ahmad \& Goparaju, 2017b; Dwyer et al., 1998; Dwyer et al., 2000) and have increased our comprehension of biomass burning (Kaufman et al., 1992), land-use/landcover change (Eva \& Lambin, 2000) pattern, and fire risk and threat mapping (Chuvieco \& Congalton, 1989). Satel lite based fire monitoring thus becomes a boon and provides a reliable source of fire events that largely overcome the limitations of traditional fire records system (Csiszar et al., 2005; Eva \& Lambin, 1998; Flannigan \& Vonder Haar, 1986; Korontzi et al., 2006). Fire is a major component contributing to carbon cycle, greenhouse gases and aerosol emissions to the atmosphere (Andreae \& Merlet, 2001; van der Werf et al., 2010) whereas biomass burning has a very critical relevance to global vegetation dynamics (Kloster et 1., 2012; Thonicke et al., 2010), increasingly influencing human lives and property (Bowman et al., 2009).

India is one of the mega-biodiversity countries which retains 173,000 forest villages largely occupied by the ethnic's communities, their life fully revolves in and around the forest for their livelihoods (Aggarwal et al., 2009).

The Orissa state has been suffering due to extreme weather condition (Ray-Bennett, 2009). It has a rich tropical forest cover mainly dominated by deciduous forests which retain lots of leaf litter during summer due to leaves shedding usually in autumn, the extreme weather such as drought dries out the vegetation, making it easier to burn and thus becomes a better fuel source of fire (Pausas \& Fernandez-Munoz, 2012). Dry deciduous forests are more vulnerable to forest fire (FAO, 2001). Orissa is one of the highest poverty incidence states of India (Mahendra Dev \& Ravi, 2007). Several starvation deaths have been reported from time to time especially to the tribal dominated pockets of this state (http://www.indiatogether.org/starve-poverty).

In the diversified landscapes of Orissa, the people occupation living close and within the forests is inextricably linked to the forest ecosystem. People depend on the forest for a variety of forest products for food, fodder, fuel, agriculture, home, and a variety of commercial minor forest produces which can potentially deteriorate forest if uti- lized in unsustainable manner. Various studies at regional level reveal that the pattern of collection of these minor forest products and its significant impact on local forest results in degradation (Mishra et al., 2008; Arjunan et al., 2005; Sagar \& Singh, 2004; Maikhuri et al., 2001; Silori $\&$ Mishra, 2001) due to huge dependency on local/tribal livelihood.

An analysis of temporal variation in monthly, seasonal and annual precipitation over the state of Orissa during the period from 1871 to 2006 revealed that a long-term in significant declining trend of annual as well as monsoon (June-September) rainfall and an increasing trend in postmonsoon season (October-November) in the state manifest the rainfall anomalies. However, the analysis also shows that a decreasing trend in monthly rainfall in of June, July and September, and an increasing trend in August more predominant in the last 10 years (Patra et al., 2012) will certainly increase forest fire period to post summer season. Similarly, analysis by Tanner et al. (2007) shows that after 1961, the rainfall patterns are below the normal, suggesting a drier spell in Orissa which will affect the forest resources having an impact on the livelihood of the poor. The state witnessed decreasing rainfall in some parts of the year (Mahapatra \& Mohanty, 2006; Patra et al., 2012) which affected entire state badly.

The climate change in Orissa shows the possibility of an increase in hydrologic extremes (Ghosh \& Majumdar, 2006) including increasing probability of severe and extreme droughts (Ghosh \& Majumdar, 2007) which will also affect the regeneration of various forest tree species (Maithani et al., 1986) including Sal (Shorea robusta). The forest of Orissa should be the biggest future challenge to policy makers in preserving and conserving forest resources in tribal dominated state.

Few studies on forest fire have been carried out in India such as Reddy et al. (2017) who quantified total burnt area extent and $\mathrm{CO}_{2}$ emissions; Giriraj et al. (2010) identified high fire prone zones area; Vadrevu et al. (2008) analyzed the spatial patterns in fire events across diversified geographical, vegetation and topographic gradients; Vadrevu et al. (2013) analyzed the various fire regime; Ahmad and Goparaju (2017a) identified forest fire hotspot districts in Jharkhand state; Ahmad et al. (2017) studied the Jharkhand state fire trends, identified the forest fire hotspot and evaluated the climate data for establishing the relationship to forest fire events.

Why this study is important?

1. The study area is largely dominated by deciduous forests which occupy a large part of Orissa. The dry deciduous forests are more vulnerable to forest fire (FAO, 2001) and are deteriorating at an alarming rate.

2. The understanding of relationship of fire events with various other parameters such as vegetation type, 
forest boundary, tribal population etc. has not been adequately manifested by research finding.

3. The states of Orissa have significant percent of population living below poverty line whereas the tribal population largely living in and around of the remote areas of forest are suffering from acute poverty and diminishing livelihood. Climate induced forest fire is one of the reasons which leads to degradation and reduction of the existing forest resource.

The present study has utilized the 16 years MODIS based fire datasets for the whole of Orissa (point data of location of forest fire) and analyzed it in GIS domain towards visualization and evaluating the spatial/temporal dimension of fire pattern.

The objectives of the present study are as follows:

1. The month wise fire events analysis throughout the year.

2. The fire events evaluation along all the administrative units/districts.

3. Forest fire hotspots analysis.

4. Evaluation of fire events and its distribution across the different vegetation types, topographical gradient, tribal population and future climate change scenario (RCP-6).

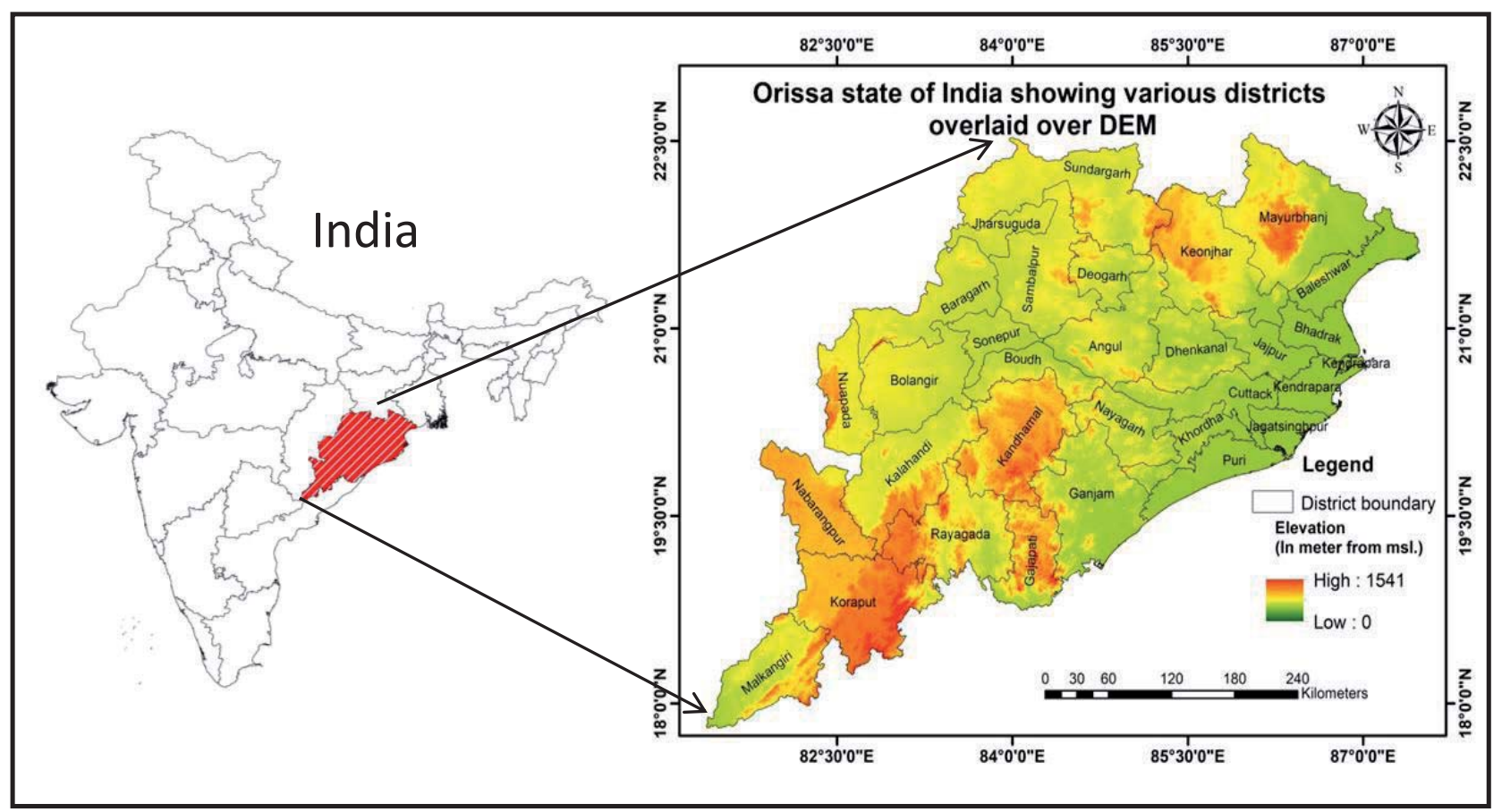

\section{Materials and methods}

\subsection{Study area}

This study was carried out in the state of Orissa which has total number of 30 districts which are spread over an area of $155,707 \mathrm{~km}^{2}$, and are bounded between North latitudes $17^{\circ} 49^{\prime}$ to $22^{\circ} 34^{\prime}$ and East longitude $81^{\circ} 24^{\prime}$ to $87^{\circ}$ 29'. All thirty districts were included in the study (Fig. 1). Major forest types of total forest area of these regions are moist deciduous forest (75\%) followed by dry deciduous forest $(21.3 \%)$, semi evergreen forest $(3.1 \%)$ and mangrove (0.6\%) (Reddy et al., 2013).

The degradation of forests in the Orissa state is due to various reasons, such as forest fire, agriculture practice, over grazing, mining, quarrying, excessive fuel wood collection and over exploitation of minor forest produce. The cause of fires is largely by anthropogenic reason which spread accidentally due to negligence and intentionally.

The local inhabitant use to clear the land for various purposes as per their needs. In tropical dry deciduous forest, the villagers start clearing the ground for collecting the mahua (Madhuca indica) flower from the end of February whereas people/contractor deliberately put fire to enhance better flushes for tendu (Diospyros melanoxylon) leaves which fetch them more money in form of revenue.

Figure 1 . The location of the study area 
Agriculture practices by clearing the area largely by the poor inhabitant for their livelihood are also one of the reasons for forest fire in this region. The forest fire incidences are noticed high during this peak summer season, which coincides with the period of high amounts of fuel load available on the forest floor. Agriculture residue burning is also a common practice by the farmers, a kind of preparation of agriculture field for growing other crops.

The study of the Reddy et al. (2014) in Orissa state reveals that the loss of dense forest and annual forest loss from year 1975 to 2010 was equivalent to $10,679 \mathrm{~km}^{2}$ and $228 \mathrm{~km}^{2} /$ year respectively.

\subsection{Data and analysis}

The boundary of Orissa state and districts were downloaded from DIVA GIS website (http://www.diva-gis.org/ Data). Moderate Resolution Imaging Spectroradiometer (MODIS) Collection 6 Active Fire Product (MODIS C 6) having resolution of $1-\mathrm{km}$ used to quantify fire risk of the state of Orissa, India. We utilized the fire counts data from the year 2-11-2000 to 31-12-2016 was in the point shape file provided as download by NASA Fire Information for Resource Management System (FIRMS) team (https:// firms.modaps.eosdis.nasa.gov).

Fire data quality was evaluated based on specific software by the MODIS land quality assessment team to ensure its high standard (Roy et al., 2002). The SPOT4 sat- ellite based vegetation cover derived from 'Vegetation instrument' having $1 \mathrm{~km}$ resolution is VEGA 2000 dataset was downloaded for the present study (http://forobs.jrc. ec.europa.eu/products/glc2000/glc2000.php). The legends of vegetation cover were defined by FAO. South central Asian regional datasets (Roy et al., 2003) described various vegetation types was utilized for this study. The fire events in each vegetation type were evaluated. The tribal population and forest density maps were produced from the existing literatures. We have utilized digital elevation model GTOPO30 downloaded from USGS website. The DEM retain grid spacing of 30 arc seconds (roughly 1 kilometer).

The fire season temperature and the annual rainfall anomalies (climate change scenario) data for the year 2030 over the state of Orissa were downloaded using RCP-6 scenario model (NCAR GIS Program, 2012). The data downloaded was in point grid. The temperature and rainfall surface were generated from the point vector file using the kriging interpolation technique because it gives the best linear unbiased prediction of the intermediate values. MODIS fire points data were in the form of vector shape file applied for examining its trend and relationship with various gradients such as month wise, administrative boundary, vegetation classes, tribal population, forest density, slope and elevation. The ARC/GIS, Erdas Imagine Software and Microsoft Excel were utilized significantly for generation of various themes, cross evaluation to achieve the above mentioned objectives.

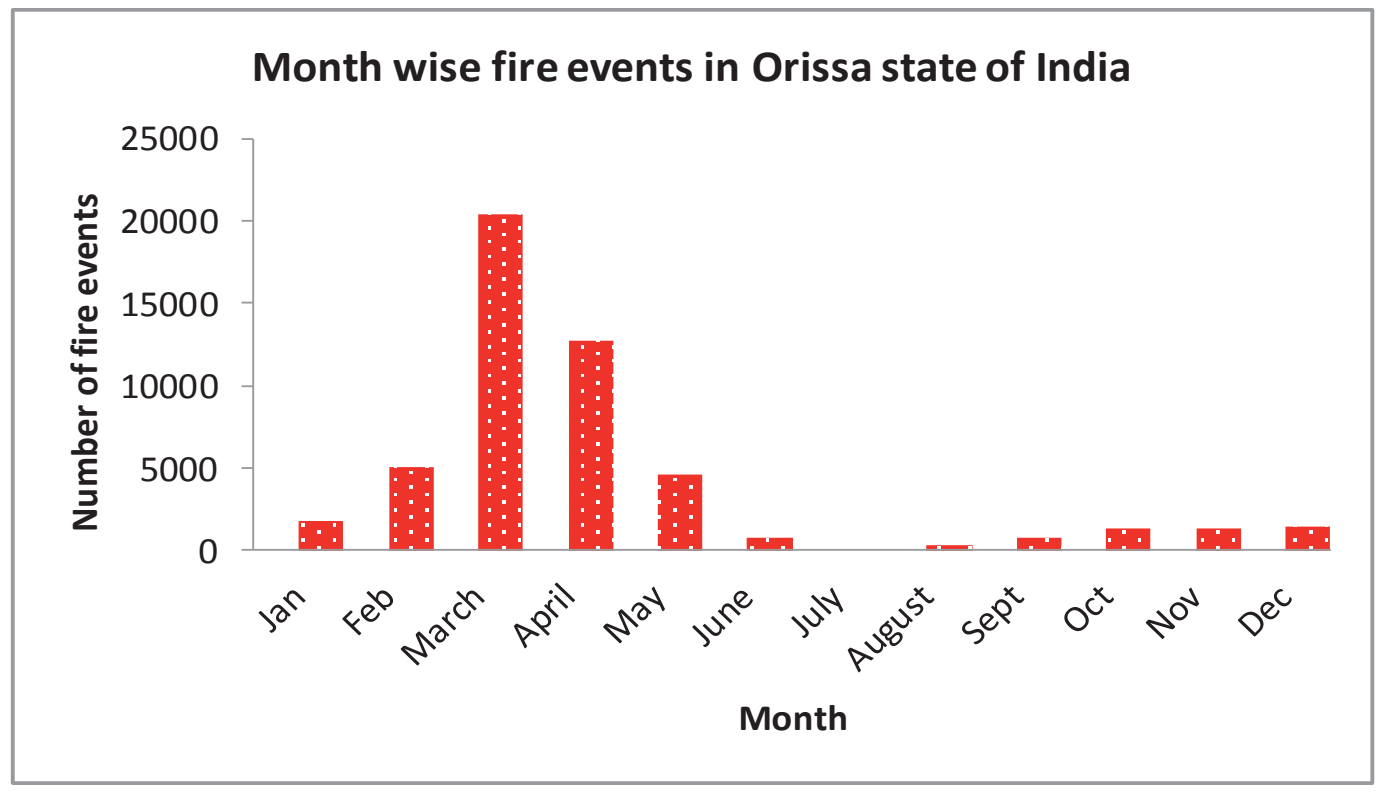

Figure 2. The fire events month wise over state of Orissa 


\section{Results}

\subsection{Fire assessment month wise/season}

Spatial distribution and its evaluation of fire are important as it helps in prevention, mitigation and control. Long term fire data was analyzed in GIS domain to understand the month wise pattern. The total number of fire count in Orissa states was found 51,343 between the periods 2-11-2000 to 31-12-2016 and are represented in the graph. The fire frequencies have been examined on monthly basis from January to December. It was observed that the $85 \%$ forest fire events are in February, March, April and May during the months of summer season (Fig. 2). Similar finding has been observed by Ahmad et al. (2017) in adjacent state of Jharkhand.

The fire events have been examined over Orissa among the 30 districts administrative boundary. Here we have integrated forest fire percent and also the forest cover area percent district wise based on FSI (2015) report. The total forest area in this state of Orissa is equivalent to 50,354 square kilometer based on FSI 2015 report. The integrated fire occurrence percent and forest cover area percent district wise given in Figure 3.

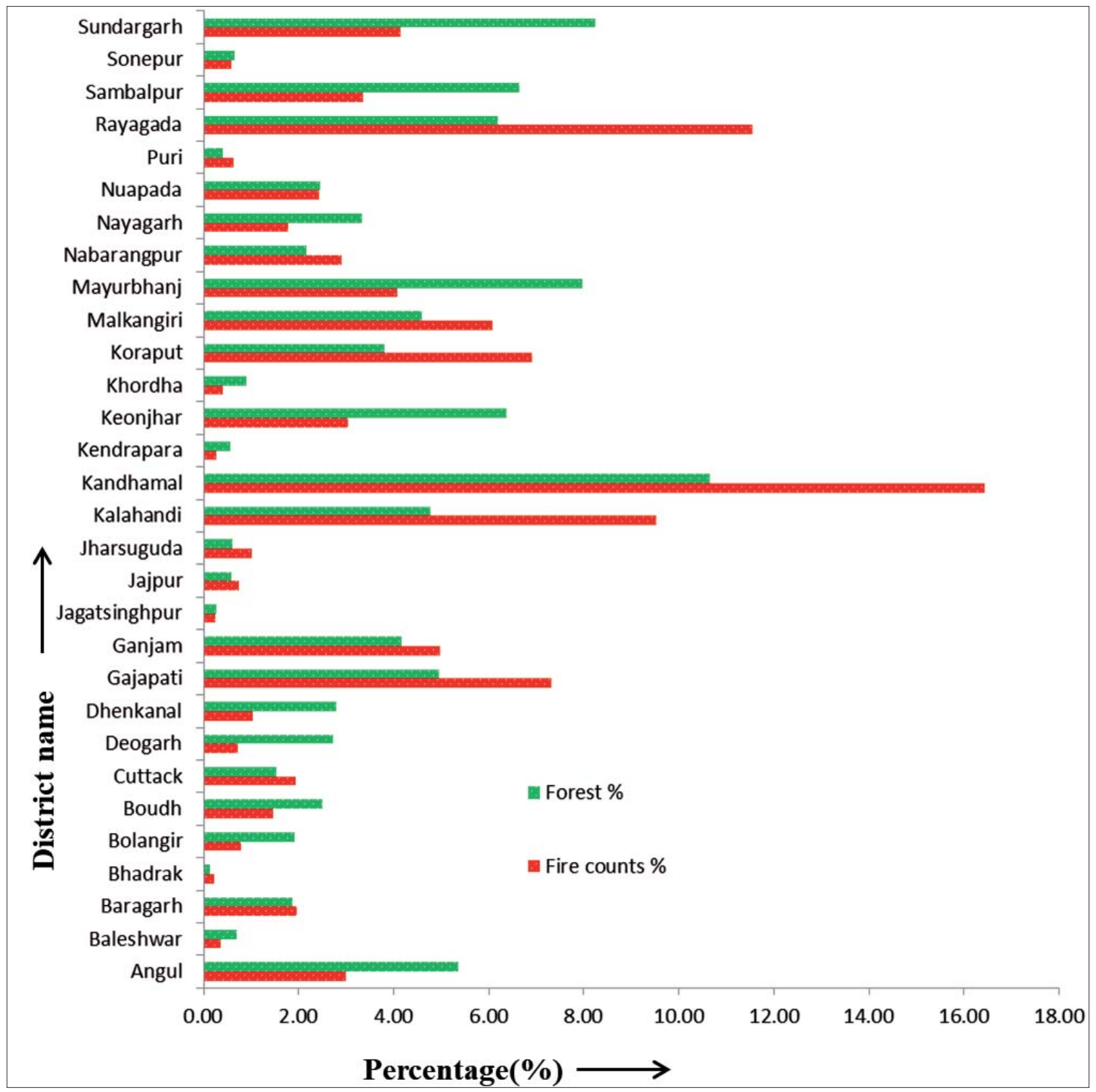

Figure 3. Fire events and forest area percent of various districts of Orissa 
Kandhamal, Raygada and Kalahandi district represents around $22 \%$ of Orissa forest cover (considering total forest cover of Orissa $100 \%$ ) whereas it represents $38 \%$ of Orissa fire frequency. Similarly Mayurbhanj is one of the least affected districts from fire (4\%) even though it is the 3 rd district showing high forest cover percentage (8\%). Mayurbhanj district villagers use community based forest management practice that has enabled them to protect the forest more effectively (Sinha \& Singh, 2017).

\subsection{Fire assessment with vegetation gradient}

The derived vegetation cover was analyzed with respect to the fire events. The map, area and fire percent of various vegetation types are given in the Figure 4 for general understanding and discussion. The two vegetation type "Tropical mixed deciduous and dry deciduous forests" and "Tropical lowland forests, broadleaved, evergreen, $<1000$ m" occupy the geographical area roughly $43 \%$ whereas they retain fire percent equivalent to $70 \%$ which is a serious concern. Similar finding was observed by FAO where they found deciduous forests are prone to fire (http://www.fao.org/docrep/006/AD653E/ad653e50.htm\#P5391_387485).

The vegetation type "Cropland, irrigated, inundated or flooded" however occupy 44\% geographical area mostly dominated in plain with high soil fertility status widely practiced for growing agriculture crop (paddy, wheat and pulse etc.) exhibit $14 \%$ fire events mostly due to agriculture residues burning by farmers. Similar finding was observed by Vadrevu et al. (2008). Major industries and factories are located in the vicinity of the urban area in Orissa. The chimney outlet of smoke is detected as fire points in our analysis are the reason for more fire percent in urban areas.

\subsection{Forest fire hotspot analysis}

The vegetation categories representing the forest were merged from vegetation data to understand the fire events in forest. The whole 16 year data of MODIS fire events were first masked with forest area to eliminate non forest fire points. The remaining fire points were integrated in ARC/GIS Software simultaneously by utilizing "point density" sub-module for generating continuous surface of the forest fire hotspot and its spatial pattern (Fig. 5) in the state of Orissa (Ahmad et al., 2017). The spatial pattern that shows most of the south western portion of Orissa state is affected by forest fire. The southern part of Kandhamal district is highly affected by forest fire and is represented by colour blue in Figure 5.

We have also identified four worst forest fires affected villages such as Tumudibandh, Solaguda, Gadapur and Birikota falls on forest fire hotspot area which need high priority for forest fire prevention and control. Similar find- ing has been observed by Reddy et al. (2014) where they highlighted these areas for conservation prioritization. The availability of comprehensive and significantly accurate datasets of fires (Stocks et al., 2002) helps us to identify forest fire spatial pattern (Gedalof, 2011) and assist in the management and prevention of forest fire.

\subsection{Overall assessment forest fire on tribal population and forest density}

In this analysis we have used the existing map (http://www. orissalinks.com/orissagrowth/archives/5015) for generating the tribal population map, which was brought in GIS domain (Fig. 6A). The forest map of the area generated using the existing vegetation types map by merging vegetation class representing the forest is given in the Figure $6 \mathrm{~B}$. We have also analyzed the fire events with the existing forest density map (http://www.orissalinks.com/orissagrowth/ topics/others/orissa-forests). The results reveal that $57 \%$ of fire is found in the dense forest area whereas $43 \%$ of fire was in the open forest area. This is also one of the major threats to the forest of Orissa (Reddy et al., 2014) which is at a great risk of diminishing livelihood among the tribal community (Aggarwal et al., 2009).

The fire counts were masked using the forest map which means it only represents the fire count in forest area. The tribal population percent map categorized into four classes based on their population percent viz. low $(<20)$, medium (20-35), high (35-50) and very high $(>50)$. The study reveals that $52.2 \%$ forest fire counts falls in very high tribal dominated area (Fig. 7).

Roughly $70 \%$ of forest fire occurs in the area where tribal population was high to very high. This affects the critical linkage of livelihood-forest of a huge forest dependent tribal population (Davidar et al., 2010) including traditional foods important to them (Lynn et al., 2013).

\subsection{Topographical data analysis}

The thematic layer such as elevation and slope were extracted from the digital elevation model. These themes were examined in GIS domain with existing fire incidences data. The analysis of fire events based on the elevation and slope range is given in the Figure $8 \mathrm{~A}$ and Figure $8 \mathrm{~B}$. These results suggest that the maximum percent of forest fire $(32 \%)$ occurred in the higher elevation $(>700$ meter) equivalent to the area $17.2 \%$ whereas roughly $60 \%$ of forest fire occurred where elevation was greater than 500 meter.

The analysis of slope shows that the most of the forest fire $(48 \%)$ occurs to moderate slope gradient (2 to 6 degree).Wind speed and temperature are characterized by elevation is an important physiographic factor hence affects the fire susceptibility (Rothermel, 1991) whereas 

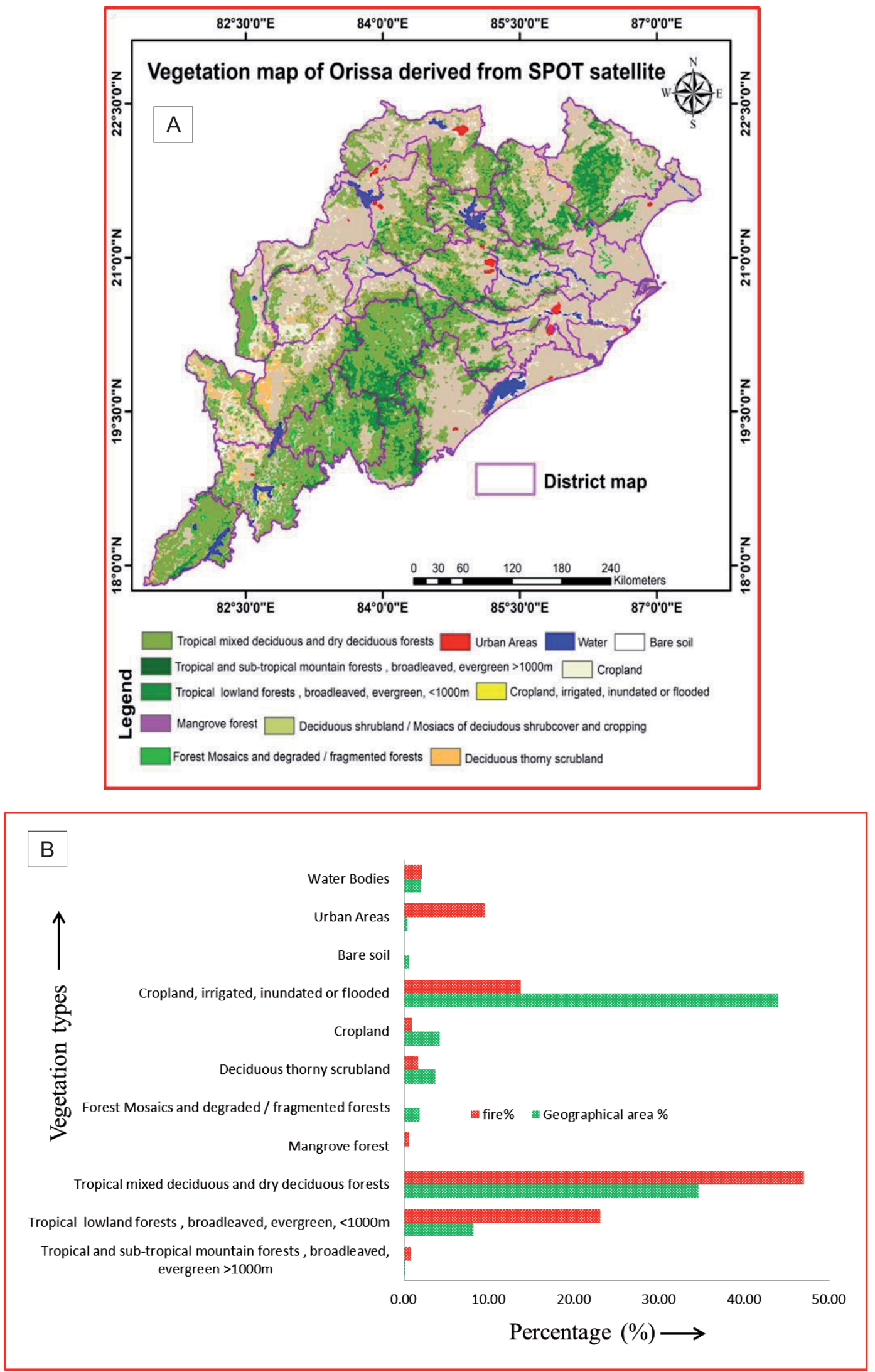

Figure 4. Vegetation map in state of Orissa (A) and Fire events \% along various vegetation types in state of Orissa (B) 


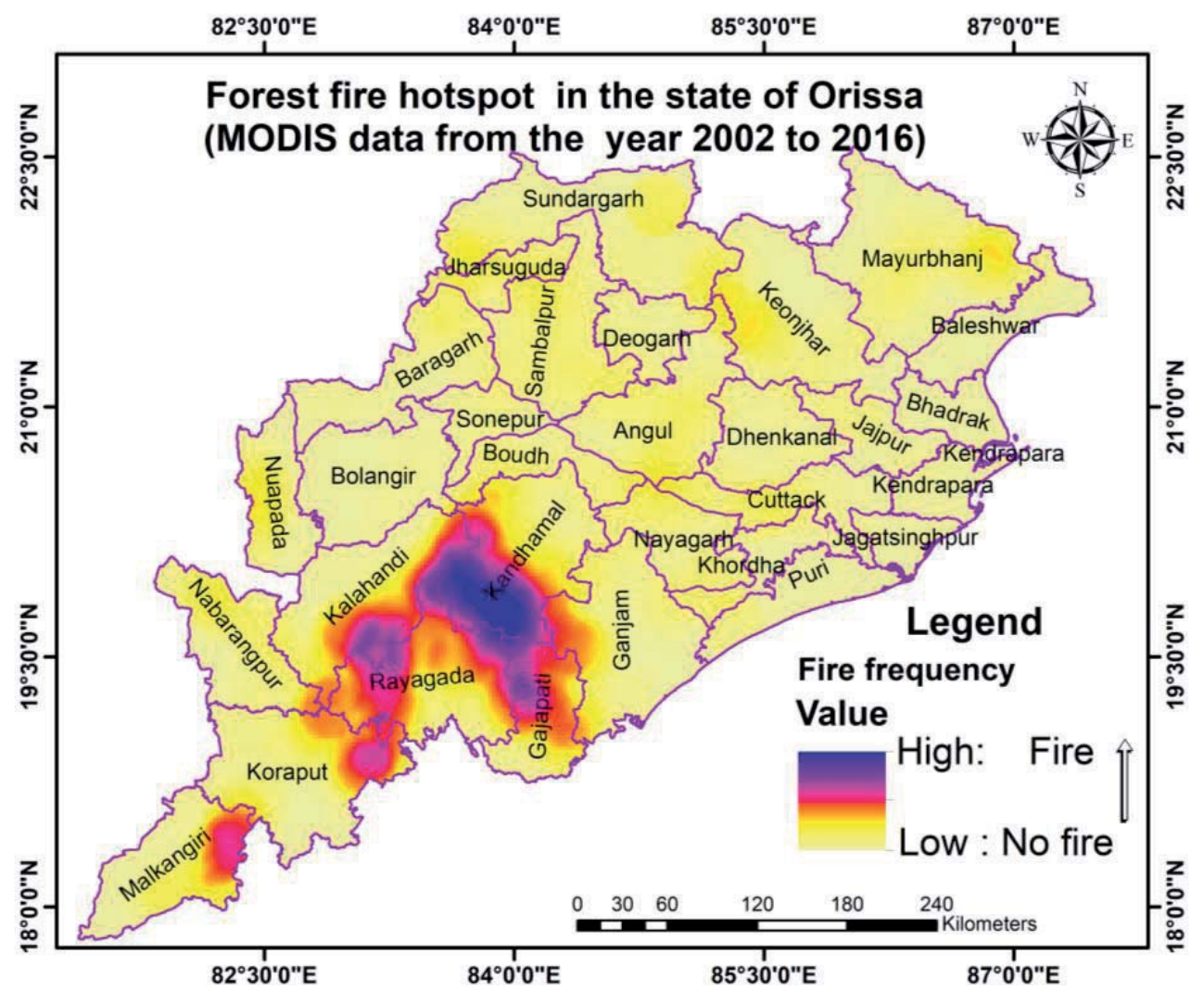

Figure 5. The MODIS based forest fire hotspot map of Orissa
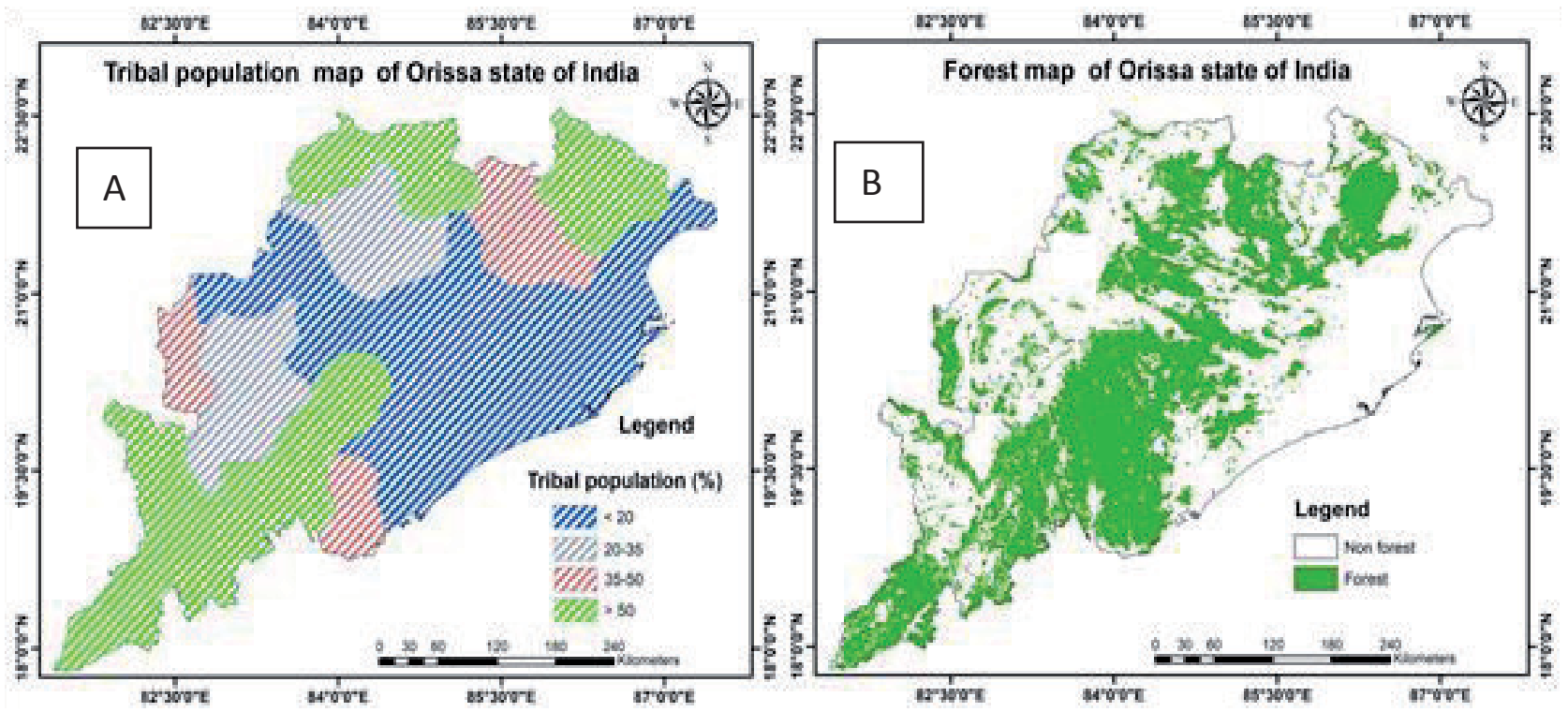

Figure 6. Tribal population map (A) and Forest map (B) 


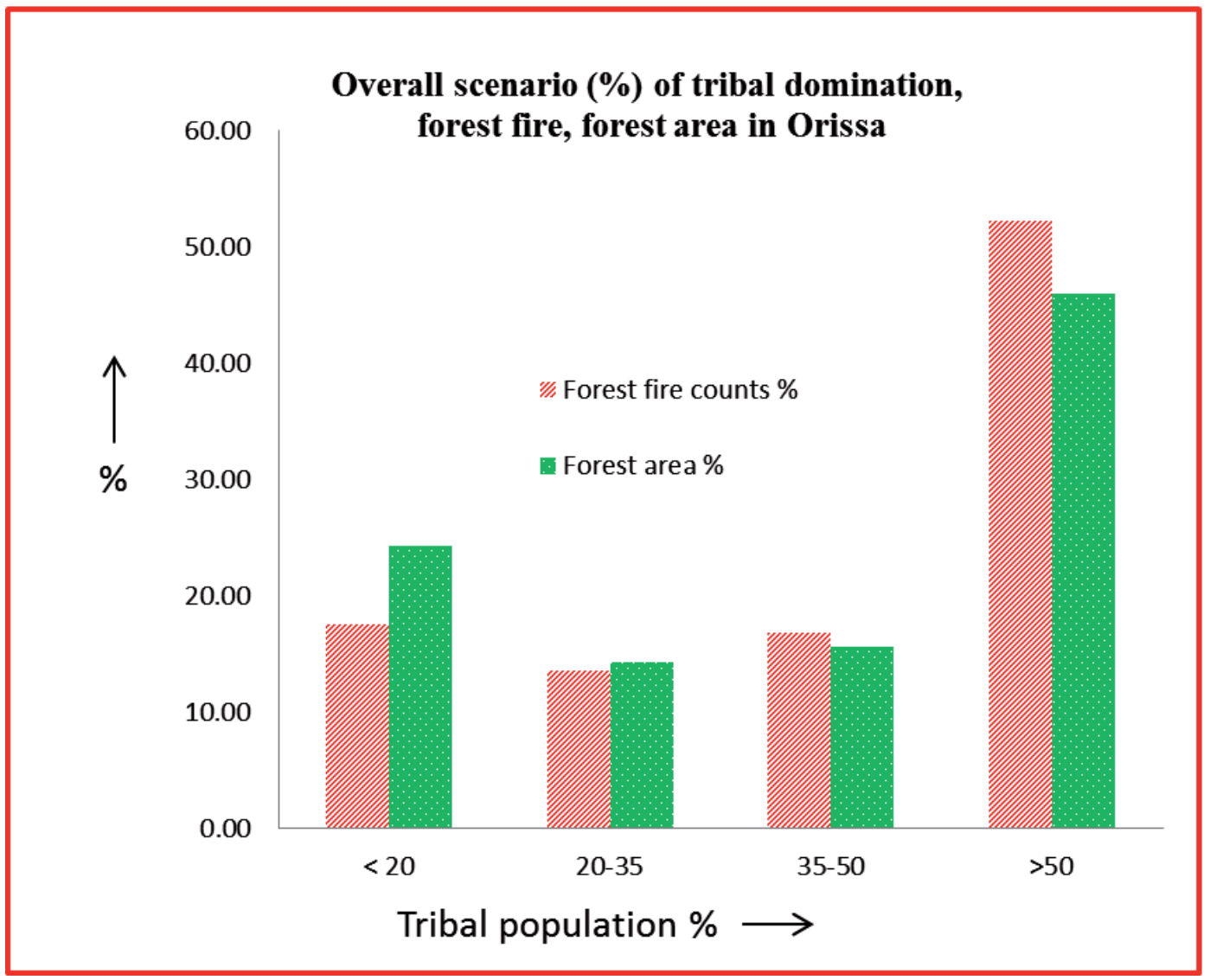

Figure 7. Overall scenario (\%) of tribal domination, forest fire, forest area in Orissa

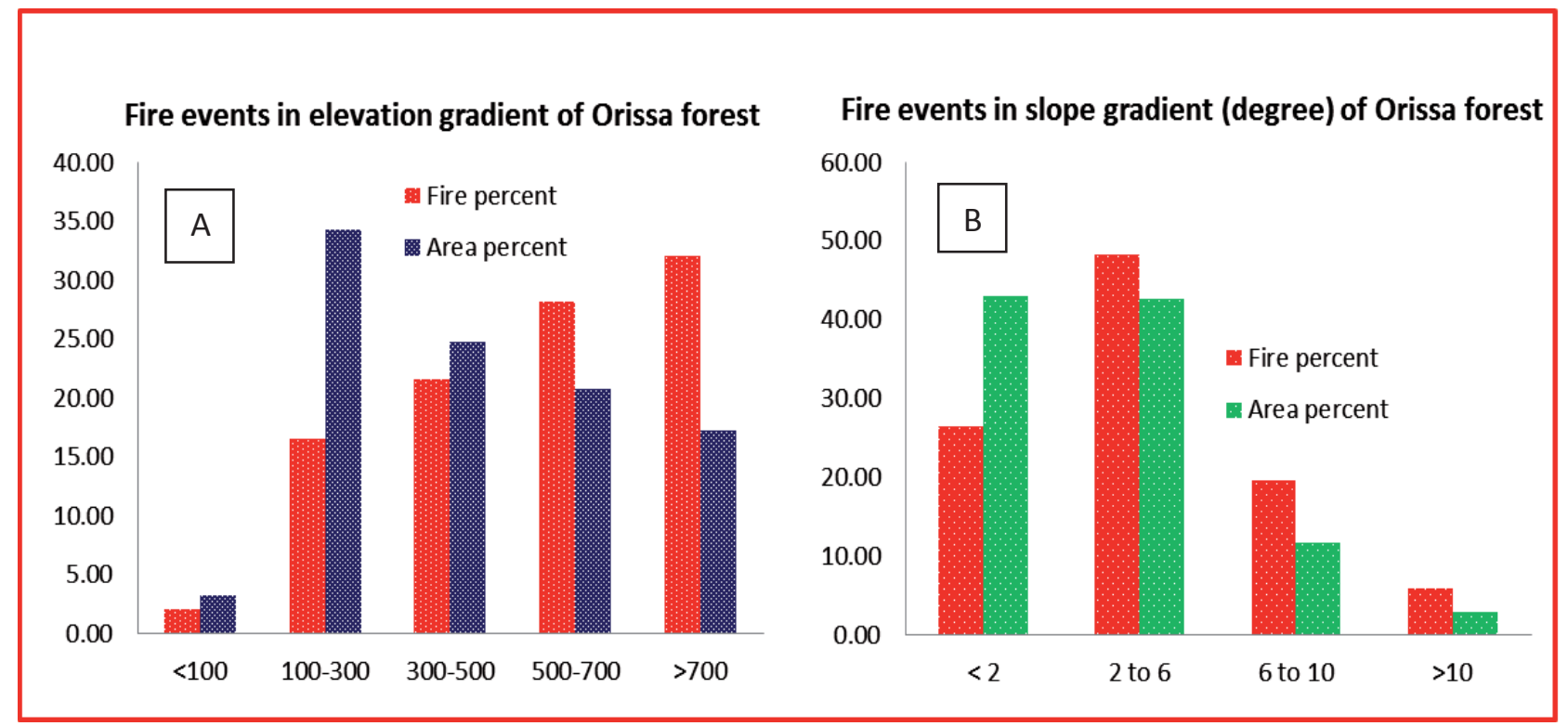

Figure 8. Fire events in elevation gradient (A) and Fire events in slope gradient (B) 
forest fire usually spreads faster in uphill than downhill thus steeper the slope faster the fire movement (Kushla \& Ripple, 1997).

\section{Discussion}

\subsection{Climate anomalies and its impact}

Here we have analyzed the future climate change scenario for the year 2030. The produced temperature anomalies map showing the prediction for the year 2030 (RCP-6 sce- nario model) in the month of February, March, April, May and June are given in Figure 9, Figure 10, Figure 11, Figure 12 and Figure 13 respectively. Similarly the Figure 14 shows the annual precipitation anomaly for the year 2030(RCP-6 scenario model).

These maps were further examined to understand the future forest fire scenario. The climate anomalies map for the year 2030 show the temperature will increase during the fire season over the all districts of Orissa. The increase in temperature is found to be highest in the districts of Kandhamal, Raygada and Kalahandi (highest forest fire districts) in the month of February and March (Figs 9 $82^{\circ} 30^{\circ} 0^{\mathrm{E} E}$

$84^{\circ} 0^{\circ} 0^{\circ E}$

85 $30^{\circ} 0{ }^{\circ} \mathrm{E}$

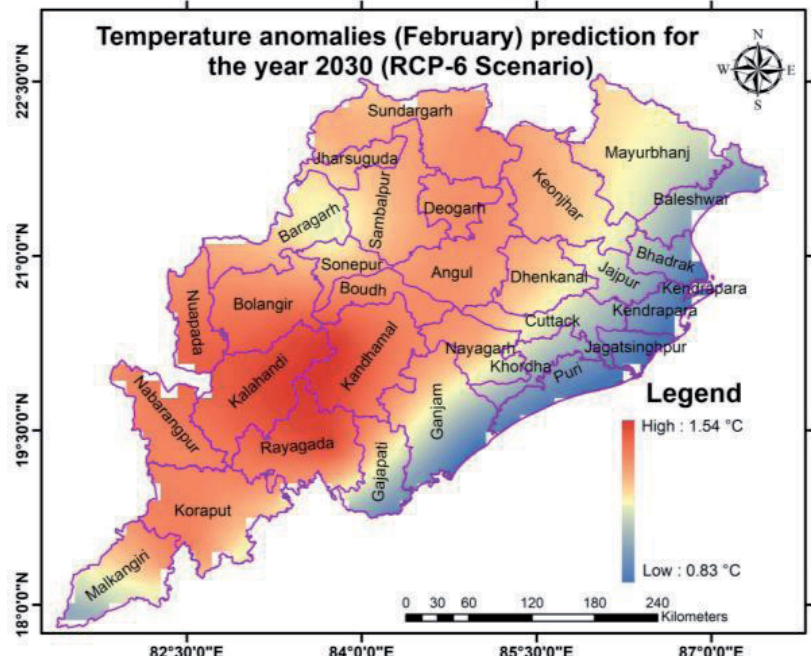

Figure 9. Temperature anomaly (February)

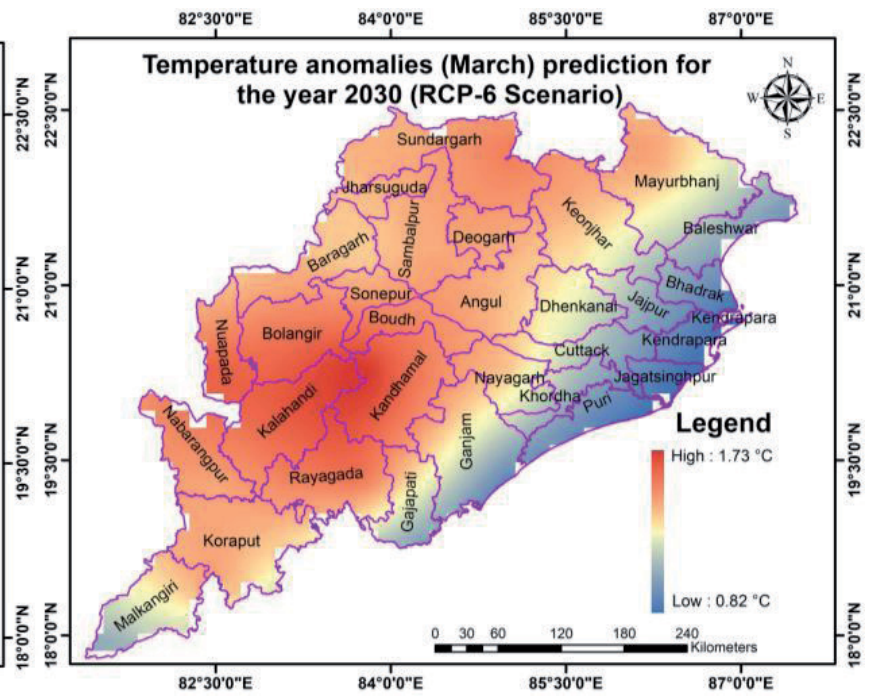

Figure 10. Temperature anomaly (March)

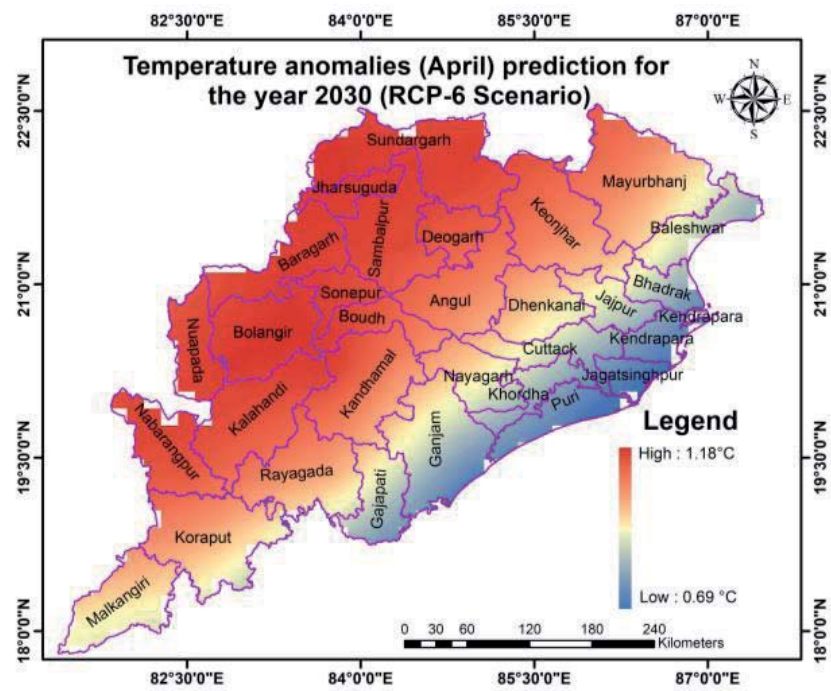

Figure 11. Temperature anomaly (April)

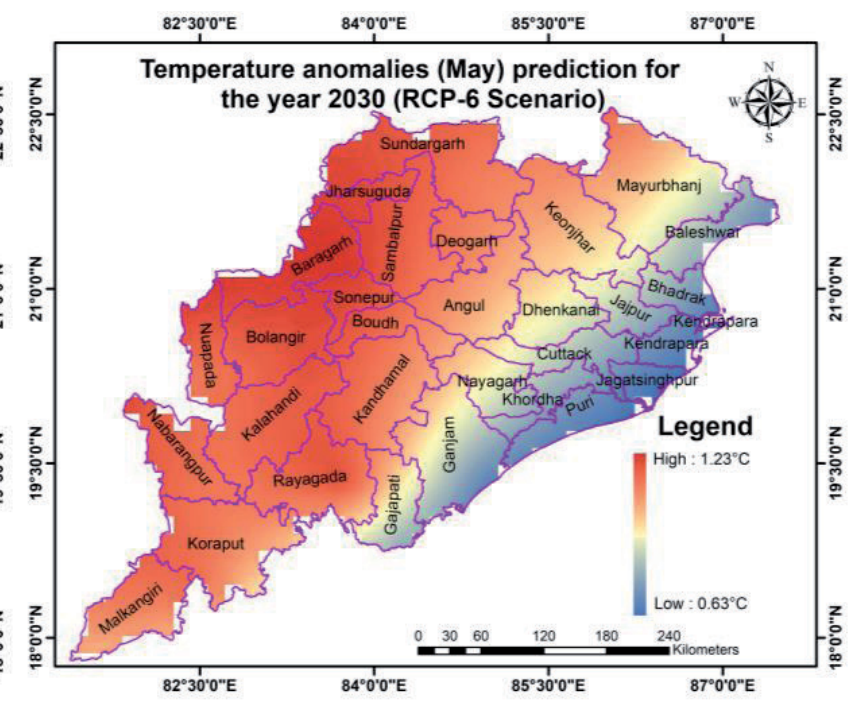

Figure 12. Temperature anomaly (May) 


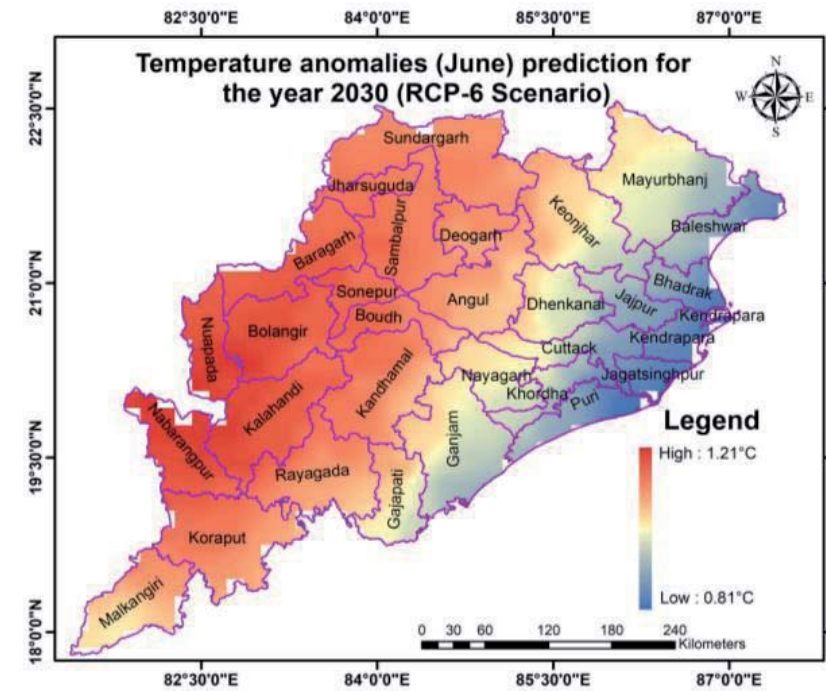

Figure 13. Temperature anomaly (June)

and 10). The annual precipitation decreasing trend was observed in the district of Kandhamal, Raygada and Koraput. Our observation of future climate change scenario for the year 2030 reflects the forest fire will be more in the state of Orissa whereas it is more severe in few of the district such as Kandhamal, Raygada, Kalahandi and Koraput which have significantly high forest fire events.

A recent study by Ahmad et al. (2017) reveals that the weather and climate parameter has strong association with forest fire events in deciduous forests. Studies in the past reveal that the climate of a region has a major control on fire activity (Krawchuk \& Moritz, 2011; Westerling et al., 2003), seasonal trends in maximum temperature, precipitation, and drought severity (Wells et al., 2004) is a major player it wildfire frequency and the extent of damage.

Study conducted by Vorobyov (2004) of the impacts on weather severity on fire, revealed that for an average temperature increase in $1^{\circ} \mathrm{C}$, the duration of wild fire season increase by $30 \%$. Climate variability and change are likely to adversely affect the livelihood of poor and tribal people in forest dominated area of Orissa due to degradation of forest.

\section{Conclusion}

The above study had utilized 16 years fire datasets and analyzed it in GIS domain towards further visualizing the spatial dimension of fire trend, pattern analysis and identifying the forest fire hotspots in Orissa and to understand their interrelationship with other parameters.

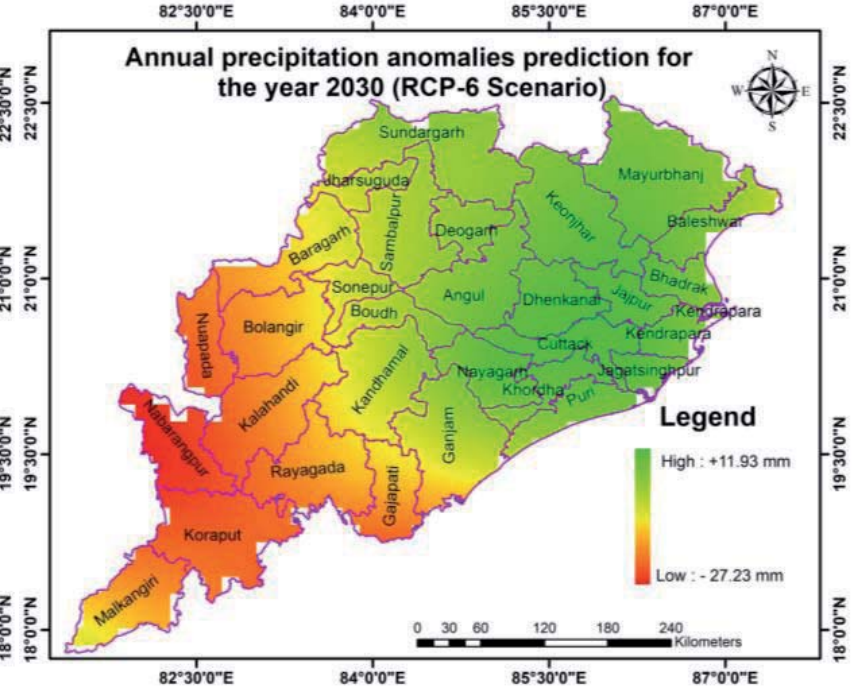

Figure 14. Annual precipitation anomaly

There is a need to monitor the forest fire hot spot zone because these areas are dominated by the tribal people and their livelihood is significantly reduced. The government should initiate more robust programme in high forest fire districts in the line of Joint Forest Management (JFM) by meaningfully involving village/ tribal people and encourage them to combat the forest fires. This can be achieved by involving the village level committees monitored by elected representatives.

In the above study, it was found that high to very high tribal population areas had suffered from the aftermath of forest fire and their livelihood is threatened. These areas need some long term special strategies must be jointly tackled (politically, socially and administratively) to revive the livelihood and to mitigate the poverty significantly. An alternative livelihood and forest conservation programmes are required to enhance the income of tribal people suffering with poverty based on sustainable livelihood approach (http://www.fao.org/3/a-ah252e.pdf) by utilizing local administrative unit and NGOs.

The evaluation of future climate data (RCP-6 scenario model) for the year 2030 show the temperature will increase during the fire season over the all districts of Orissa whereas it will be more crucial for some of the highest forest fire districts because of the significant increase in temperature in the month of February and March. The decreasing trend in annual precipitation was observed in few of the highest forest fire districts.

There is a need to formulate and implement the robust forest fire policy based on the evaluation of socio economic condition of ethnic tribes and the future climate 
change scenario. Furthermore, the state government should increase their effectiveness to prevent and control forest fire by mean of manpower, funds, equipment and technology.

Regular scientific monitoring and qualitative research studies are solicited by utilizing the fire events, climate, socioeconomic, tribal population, livelihood and other dependent parameters to understand the phenomenon at close quarters which will further enhance the policy related issues.

\section{Acknowledgements}

The authors are grateful to the USGS, NASA Fire Information for Resource Management System, European Commission's science and knowledge service, DIVA GIS for providing free download of various dataset used in the analysis.

\section{References}

Ager A.A., Evers C.R., Day M.A., Preisler H.K., Barros A.M.G. \& Nielsen-Pincus M., 2017, Network analysis of wildfire transmission and implications for risk governance. PLoS ONE12(3): e0172867-e0172894. (https://doi.org/10.1371/journal.pone.0172867).

Aggarwal A., Paul., V. \& Das S., 2009, Forest Resources: Degradation, Livelihoods, and Climate Change, [in:] D. Datt, S. Nischal (eds), Looking Back to Change Track. TERI 219, New Delhi: 91-108.

Ahmad F. \& Goparaju L., 2017a, Geospatial Assessment of Forest Fires in Jharkhand (India). Indian Journal of Science and Technology 10(21): 1-7. (doi: 10.17485/ ijst/2017/v10i21/113215).

Ahmad F. \& Goparaju L., 2017b, Assessment of Threats to Forest Ecosystems Using Geospatial Technology in Jharkhand State of India. Current World Environment 12(2): 355-365. (http://dx.doi.org/10.12944/ CWE.12.2.19).

Ahmad F., Goparaju L., Qayum A. \& Quli S.M.S., 2017, Forest fire trend analysis and effect of environmental parameters: A study in Jharkhand State of India using Geospatial Technology. World Scientific News 90: 3150.

Andreae M.O. \& Merlet P., 2001, Emission of trace gases and aerosols from biomass burning. Global Biogeochemical Cycles 15(4): 955-966. (https://doi. org/10.1029/2000GB001382).

Arjunan M., Puyravaud J.-Ph. \& Davidar P., 2005, The impact of resource collection by local communities on the dry forests of the Kalakad-Mundanthurai Tiger Reserve. Tropical Ecology 46: 135-144.
Bond W.J. \& Keeley J.E., 2005, Fire as a global "herbivore": The ecology and evolution of flammable ecosystems. Trends Ecol. Evol. 20(7): 387-394.

Bowman D.M., Balch J.K., Artaxo P., Bond W.J., Carlson J.M., Cochrane M.A., D’Antonio C.M., DeFries R.S., Doyle J.C., Harrison S.P., Johnston F.H., Keeley J.E., Krawchuk M.A., Kull C.A., Marston J.B., Moritz M.A., Prentice I.C., Roos C.I., Scott A.C., Swetnam T.W., van der Werf G.R. \& Pyne S.J., 2009, Fire in the earth system. Science 324(5926): 481-484.

Chuvieco E. \& Congalton R.G., 1989, Application of remote-sensing and geographic information-systems to forest fire hazard mapping. Remote Sensing of Environment 29(2): 147-159.

Csiszar I., Denis L., Giglio L., Justice C.O., \& Hewson J., 2005, Global fire activity from two years of MODIS data. International Journal of Wildland Fire 14(2): 117130.

Davidar P., Sahoo S., Mammen P.C., Acharya P., Puyravaud J.P., Arjunan M., Garrigues J.P. \& Roessingh K., 2010, Assessing the Extent and Causes of Forest Degradation in India: Where do we Stand? Biological Conservation 43(12): 2937-2944.

Dwyer E., Gregoire J.M. \& Malingreau J.P., 1998, A global analysis of vegetation fires using satellite images: Spatial and temporal dynamics. Ambio 27(3): 175-181.

Dwyer E., Pinnock S., Gregoire J.M. \& Pereira J.M.C., 2000, Global spatial and temporal distribution of vegetation fire as determined from satellite observations. International Journal of Remote Sensing 21(6-7): 12891302.

Eva H. \& Lambin E.F., 1998, Burnt area mapping in Central Africa using ATSR data. International Journal of Remote Sensing 19(18): 3473-3497.

Eva H. \& Lambin E.F., 2000, Fires and land-cover change in the tropics: a remote sensing analysis at the landscape scale. Journal of Biogeography 27(3): 765-776.

FAO, 2001, Global forest fire assessment 1990-2000. FAO (Forest Resources Assessment), Rome.

Finney M.A., 2001, Design of Regular Landscape Fuel Treatment Patterns for Modifying Fire Growth and Behavior. Forest Science 47(2): 219-229.

Flannigan M.D. \& Vonder Haar T.H., 1986, Forest-fire monitoring using NOAA satellite AVHRR. Canadian Journal of Forest Research-Revue Canadienne De Recherche Forestiere 16(5): 975-982.

Flannigan M.D., Logan K.A. Amiro B.D. Skinner W.R. \& Stocks B.J., 2005, Future area burned in Canada. Clim Chang 72(1-2): 1-16.

FSI, 2015, http://fsi.nic.in/isfr-2015/isfr-2015-forest-cover. pdf [Accessed on 15th November 2017].

Gedalof Z., 2011, Climate and spatial patterns of wildfire in North America, [in:] D. McKenzie, C. Miller, D.A. Falk (eds), The landscape ecology of fire. Spring- 
er, Dordrecht: 89-116. (https://doi.org/10.1007/978-94007-0301-8_4).

Ghosh S. \& Majumdar P.P., 2007, Nonparametric methods for modeling GCM and scenario uncertainty in drought assessment. Water Resour. Res. 43(W07405): 1-19. (doi:10.1029/2006WR005351).

Ghosh S. \& Majumdar P.P., 2006, Future rainfall scenario over Orissa with GCM projections by statistical downscaling. Curr Sci. 19(6): 396-404.

Gill A.M., 1975, Fire and the Australian flora: A review. Aust. For. 38(1): 4-25.

Giriraj A., Babar S., Jentsch A., Sudhakar S. \& Murthy M.S.R., 2010, Tracking fires in India using Advanced Along Track Scanning Radiometer (A)ATSR data. Remote Sens. 2(2): 591-610.

Hicke J., Johnson M.C. Hayes J. \& Preisler H.K., 2012, Effects of bark beetle-caused tree mortality on wildfire. Forest Ecology and Management 271(2012): 81-90. (doi:10.1016/j.foreco.2012.02.005).

Kaufman Y.J., Setzer A., Ward D., Tanre D., Holben B.N., Menzel P., Pereira M.C. \& Rasmussen R., 1992, Biomass Burning Airborne and Spaceborne Experiment in the Amazonas (BASE-A). Journal of Geophysical Research 97(D13): 14581-14599. (https://doi. org/10.1029/92JD00275).

Kloster S., Mahowald N., Randerson J. \& Lawrence P., 2012, The impacts of climate, land use, and demography on fires during the 21 st century simulated by CLM-CN. Biogeosciences 9(1): 509-525. (https://doi. org/10.5194/bg-9-509-2012).

Korontzi S., McCarty J., Loboda T., Kumar S. \& Justice C., 2006, Global distribution of agricultural fires in croplands from 3 years of Moderate Resolution Imaging Spectroradiometer (MODIS) data. Global Biogeochemical Cycles 20(GB2021): 1-15. (doi:10.1029/2005GB002529).

Krawchuk M.A. \& Moritz M.A., 2011, Constraints on global fire activity vary across a resource gradient. Ecology 92(1): 121-132.

Kushla J.D. \& Ripple W.J., 1997, The role of terrain in a fire mosaic of a temperate coniferous forest. Forest Ecology and Management 95(2): 97-107.

Lynn K., Daigle J., Hoffman J., Lake F., Michelle N., Ranco D., Viles C., Voggesser G. \& Williams P., 2013, The impacts of climate change on tribal traditional foods. Climatic Change 120(3): 545-556. (doi: 10.1007/ s10584-013-0736-1).

Mahapatra M. \& Mohanty U.C., 2006, Spatio-temporal variability of summer monsoon rainfall over Orissa in relation to low-pressure systems. J. Earth Syst. Sci. 115(2): 203-218.

Mahendra Dev, S. \& Ravi C., 2007, Poverty and Inequality: all-India and States, 1983-2005. Economic and Political Weekly 42(6): 509-521.
Maikhuri R.K., Nautiyal S., Rao K.S. \& Saxena K.G., 2001, Conservation policy - people conflicts: a case study from Nanda Devi Biosphere Reserve (a World Heritage Site), India. Forest Policy and Economics 2(3-4): 355-365.

Maithani G.P., Bahuguna V.K. \& Lal P., 1986, Effect of forest fires on the ground vegetation of a moist deciduous sal (Shorea robusta) forest. Indian Forester 112(8): 646-678.

Mishra P.C., Tripathy P.K., Behera N. \& Mishra K., 2008, Socioeconomic and Socio-ecological study of Sambalpur Forest Division, Orissa. Journal of Human Ecology 23(2): 135-146.

Moritz M.A., Parisien M.-A, Batllori E., Krawchuk M.A., Van Dorn J. Ganz D.J. \& Hayhoe K., 2012, Climate change and disruptions to global fire activity. Ecosphere 3(6): 1-22. (http://dx.doi.org/10.1890/ES11-00345.1).

National Wildlife Federation (NWF), 2011, Facing the Storm: Indian Tribes, Climate-Induced Weather Extremes, and the Future for Indian Country. National Wildlife Federation Rocky Mountain Research Center, Boulder, Colorado.

NCAR GIS Program. (2012) Climate Change Scenarios, version 2.0. Community Climate System Model, June 2004 version 3.0. http://www.cesm.ucar.edu/models/ ccsm3.0/ was used to derive data products. NCAR/ UCAR. URL. (http://www.gisclimatechange.org). [Accessed on 5th March 2018].

Patra J., Mishra A., Singh R. \& Raghuwanshi N.S., 2012, Detecting rainfall trends in the twentieth century (1871-2006) over Odisha State, India. Clim. Change 111(3-4): 801-817. (doi:10.1007/s10584-011-0215-5).

Pausas J.G. \& Fernandez-Munoz S., 2012, Fire regime changes in the western Mediterranean Basin: From fuel-limited to drought-driven fire regime. Clim. Chang. 110(1-2): 215-226.

Ray-Bennett N.S., 2009, Multiple Disasters and Policy Responses in Pre- and Post-independence Orissa, India. Disasters 33(2): 274-290. (doi: 10.1111/j.14677717.2008.01074.x).

Reddy C.S., Alekhya V.V.L.P., Saranya K.R.L., Athira K., Jha C. S., Diwakar P. G. \& Dadhwal V.K. 2017, Monitoring of fire incidences in vegetation types and Protected Areas of India: Implications on carbon emissions. J. Earth Syst. Sci. 126 (11): 1-15. (doi: 10.1007/ s12040-016-0791-x).

Reddy C.S., Khuroo A.A., Harikrishna P., Saranya K.R.L., Jha C.S. \& Dadhwal V.K., 2014, Threat evaluation for biodiversity conservation of forest ecosystems using geospatial techniques: a case study of Odisha, India. Ecological Engineering 69: 287-303. (https://doi. org/10.1016/j.ecoleng.2014.05.006).

Reddy C.S., Jha C.S. \& Dadhwal V.K., 2013, Assessment and monitoring of long-termforest cover changes 
in Odisha, India using remote sensing and GIS. Environ. Monitor. Asses. 185(5): 4399-4415.

Rothermel R.C., 1991, Predicting behavior and size of crown fires in the northern Rocky Mountains, Res. Pap. INT-438. U.S. Dept. of Agriculture, Forest Service, Intermountain Research Station, Ogden, UT. (https://doi.org/10.2737/INT-RP-438).

Roy D.P., Borak J.S., Devadiga S., Wolfe R.E., Zheng M. \& Descloitres J., 2002, The MODIS Land Product Quality Assessment Approach. Remote Sensing of Environment 83(1-2): 62-76.

Roy P.S., Agrawal S., Joshi P. \& Shukla Y., 2003, The Land Cover Map for Southern Asia for the Year 2000. GLC2000 database, European Commision Joint Research Centre. (http://forobs.jrc.ec.europa.eu/products/ glc2000/products.php).

Sagar R. \& Singh. J.S., 2004, Local plant species depletion in a tropical deciduous forest of northern India. Environmental Conservation 31(1): 55-62.

Silori C.S. \& Mishra B.K., 2001, Assessment of Livestock Grazing Pressure in and around the Elephant Corridors in Mudumalai Wildlife Sanctuary, South India. Biodiversity and Conservation 10(12): 2181-2195.

Sinha B. \& Singh K.D., 2017, Achieving Conservation and Livelihood : A Case Study from Orissa, India. (https://dlc.dlib.indiana.edu/dlc/bitstream/handle/10535/7208/692.pdf?sequence $=1$ ). [Accessed on 25th December 2017].

Stocks B.J., Mason J.A., Todd J.B., Bosch E.M., Wotton B.M., Amiro B.D., Flannigan M.D., Hirsch K.G., Logan K.A., Martell D.L. \& Skinner W.R., 2002, Large forest fires in Canada, 1959-1997. Journal of Geophysical Research - Atmospheres 107(D1): 5.1-5.12. (doi:10.1029/2001JD000484).

Sturrock R.N., Frankel S.J., Brown A.V., Hennon P.E., Kliejunas J.T., Lewis K.J., Worrall J.J. \& Woods A.J., 2011, Climate change and forest diseases. Plant Pathol. 60(1): 133-149. (doi:10.1111/j.13653059.2010.02406.x).

Tanner T.M., Nair S., Bhattacharjya S., Srivastava S.K., Sarthi P.P., Sehgal M. \& Kull D., 2007, ORCHID: cli- mate risk screening in DFID India. Research report. Institute of Development Studies, Brighton. (https:// www.ids.ac.uk/files/dmfile/ORCHIDIndiaRR.pdf).

Thonicke K., Spessa A., Prentice I.C., Harrison S.P., Dong L. \& Carmona-Moreno C., 2010, The influence of vegetation, fire spread and fire behaviour on biomass burning and trace gas emissions: Results from a processbased model. Biogeosciences 7(6): 1991-2011.

Vadrevu K.P., Badarinath K.V. \& Anuradha E., 2008, Spatial patterns in vegetation fires in the Indian region. Environ Monit Assess. 147(1-3): 1-13. (doi: 10.1007/ s10661-007-0092-6).

Vadrevu K.P. Csiszar I., Ellicott E., Giglio L., Badarinath K. V. S., Vermote E.\& Justice C., 2013, Hotspot analysis of vegetation fires and intensity in the Indian region IEEE J. Sel. Top. Appl. Earth Obs. Remote Sens. 6(1): 224-38. (doi: 10.1109/JSTARS.2012.2210699).

van der Werf G.R., Randerson J.T., Giglio L., Collatz G.J., Mu M., Kasibhatla P.S., Morton D.C., DeFries R.S., Jin Y., \& van Leeuwen T.T., 2010, Global fire emissions and the contribution of deforestation, savanna, forest, agricultural, and peat fires (1997-2009). Atmospheric Chemistry and Physics 10 (23): 11707-11735. (https:// doi.org/10.5194/acp-10-11707-2010).

Voggesser G., Lynn K., Daigle J., Lake F.K. \& Ranco D., 2013, Cultural impacts to tribes from climate change influences on forests. Clim Chang. 120(3): 615-626. (doi:10.1007/s10584-013-0733-4).

Vorobyov Y., 2004, Climate change and disasters in Russia, [in:] Y. Izrael, G. Gruza, S. Semenov, I. Nazarov (eds), Proc. World Climate Change Conference, Moscow. Institute of Global Climate and Ecology, Moscow: 293-298.

Wells N., Goddard S. \& Hayes M.J., 2004, A self-calibrating Palmer Drought Severity Index. J. Clim. 17(12): 2335-2351.

Westerling A.L.,Gershunov A., Brown T.J., Cayan D.R. \& Dettinger M.D., 2003, Climate and wildfire in the western United States. Bull. Am. Meteorol. Soc. 84(5): 595-604. 